\title{
Genetic associations between visual scores, body weight and age at first calving in nellore breed cattle
}

[Associações genéticas entre escores visuais, peso corporal e idade ao primeiro parto de bovinos da raça Nelore]

F.B. Freitas $^{1}$, C.V. Araújo $^{2}$, F.L. Menezes $^{2}$, F.G. Silva ${ }^{3}$, S.I. Araújo ${ }^{2}$, H.T. Ventura ${ }^{1}$

${ }^{1}$ Associação Brasileira de Criadores de Zebú - ABCZ - Uberaba, MG

${ }^{2}$ Universidade Federal de Mato Grosso - UFMT - Sinop, MT

${ }^{3}$ Universidade Federal de Mato Grosso - UFMT - Cuiabá, MT

\begin{abstract}
Body weight records of 231,416 Nellore females obtained from the Brazilian Association of Zebu Breeders were used to determine a linear combination between visual appraisal scores (body structure, precocity and muscling) using principal components analysis (PC), and to verify their genetic association with body weight at 12 months (BW) and age at first calving (AFC). The mixed linear model included the fixed effect of the contemporary group and the linear and quadratic effects of age at calving, random effects of genetic additive, maternal environment and temporary environment. Heritability estimates for $\mathrm{BW}, \mathrm{PC}$ and $\mathrm{AFC}$ were $0.51,0.30$ and 0.17 , respectively. Genetic additive correlations between BW and PC; BW and AFC, and PC and AFC were 0.48 ; -0.31 and -0.55 ; respectively. Spearman's correlations for the best-ranked bulls based on PC prediction were positive between BW and PC and negative among the other combinations. Heritability estimates and correlations indicate potential genetic gains for BW and $\mathrm{CP}$ with reduced $\mathrm{AFC}$ in cows. The use of $\mathrm{PC}$ allows positive responses on precocity and body weight development.
\end{abstract}

Keywords: Principal components, genetic parameters, selection

\section{RESUMO}

Utilizaram-se registros de pesos corporais de 231.416 fêmeas bovinas da raça Nelore, oriundos dos registros da Associação Brasileira de Criadores de Zebu-ABCZ, com o objetivo de estabelecer, por componentes principais, uma combinação linear $(C P)$ das características de escores visuais de estrutura $(E)$, precocidade $(P)$ e musculosidade $(M)$, bem como verificar sua associação genética com o peso corporal aos 12 meses (PC) e à idade ao primeiro parto (IPP). O modelo linear misto utilizado incluiu os efeitos fixos de grupo de contemporâneos e os efeitos linear e quadrático da idade da vaca ao parto, os efeitos aleatórios genético aditivo, ambiente materno e ambiente temporário. Estimativas de herdabilidade para PC, CP e IPP foram iguais a 0,51; 0,30 e 0,17, respectivamente. Correlações genéticas aditivas entre PC e CP; PC e IPP; e, ainda, CP e IPP foram iguais a 0,48; -0,31 e -0,55, respectivamente. As correlações de Spearman para os melhores reprodutores classificados em relação à predição de CP foram positivas entre PC e CP e negativas entre as demais combinações. Estimativas de herdabilidade e de correlações indicam possibilidade de ganhos genéticos expressivos para PC e CP com redução para IPP nas fêmeas. A utilização de CP possibilita respostas favoráveis para precocidade sexual e desenvolvimento ponderal.

Palavras-chave: componentes principais, parâmetros genéticos e seleção

\section{INTRODUCTION}

The correct identification and use of superior genotypes for traits of economic importance allow for genetic improvement of cattle herds. In turn, they maximize the economic results of cattle farming when coupled with improved environmental conditions.

Recebido em 2 de agosto de 2019 
However, in cattle breeding programs, it is essential to know the importance and contribution of each variable, as well as their relationship. Therefore, choosing selection criteria accurately is crucial for successful cattle raising business.

Age at first calving is a trait intrinsically related to reproductive efficiency, which, in turn, is a criterion of high economic relevance in cattle systems. It influences the selection intensity, interferes with the generation interval and impacts the genetic gains obtained in all selection criteria.

Moreover, the use of early-maturing females has a direct influence on the extraction rate, with a positive impact on the profitability of beef cattle systems.

Visual appraisal scores are used for identifying earlier-finishing individuals with better muscling and carcass conformation, and without excessive size at maturity (Faria et al., 2009).

Koury Filho et al. (2009) stated that the use of visual appraisal scores in breeding programs allows estimating the proportion of different carcass tissues at slaughter. Moreover, it helps to identify early-finishing animals (minimum degree of finish required for slaughter), avoiding increases in adult weight.

Thus, the use of finishing precocity scores, besides contributing to the selection of earlyfinishing cattle, may also favor sexual precocity.

This study aimed to determine a linear combination between visual appraisal scores in Nellore females (body structure, precocity and muscling), using principal components analysis (PC). Moreover, we aimed to estimate genetic parameters of this linear combination for body weight at 12 months of age and age at first calving, and to verify if there is a genetic association between these traits that would allow a reduction in age at first calving in Nellore females.

\section{MATERIAL AND METHODS}

Body weight records of 231,416 Nellore females from the Genetic Improvement Program of Zebu breeds were used. These animals were born from the mating of 6,714 bulls and 166,299 cows belonging to 17 herds kept in pasture-based systems from 1991 to 2015. Data were obtained from the Brazilian Association of Zebu Breeders - ABCZ.

Records of animals born from embryo transfer or in vitro fertilization and animals with no genealogical information were not considered. The measurement period corresponds to the months of lowest and highest rainfall (from April to September and from October to March).

The fixed effects of herd, year, and measurement period were used to create contemporary groups, which were used for the analysis of body weight and body structure $(\mathrm{S})$, finishing precocity $(\mathrm{P})$ and muscling (M). Cow's age at calving was used as a covariate (linear and quadratic effects), with a mean estimated at $79.26 \pm 35.43$ months of age.

Data on body weight was limited to animals ranging from 10 and 14 months of age, while data on $\mathrm{S}, \mathrm{P}$ and $\mathrm{M}$ were limited to measurements taken between 8 and 14 months of age. The age at first calving (AFC) was considered between 22 and 36 months of age.

Data on $\mathrm{S}, \mathrm{P}$ and $\mathrm{M}$ records were submitted to principal component analysis using the first principal component. Subsequently, data on body weight and first principal component were standardized at 12 months of age using the

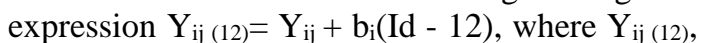
$\mathrm{Y}_{\mathrm{ij}}, \mathrm{B}_{\mathrm{i}}$ and Id are the given standardized variable at 12 months, non-standardized variable, linear regression coefficient of a given variable as a function of measurement age, and measurement age, respectively.

Only standardized 12-month-old data on body weight (BW) and principal component (PC) within three standard deviations of the mean of the specific contemporary group were used. A minimum of four records per contemporary group were considered, as well as bulls with more than two progenies.

The mixed linear model used for estimation of (co)variance components and prediction of genetic values was as follows: $y=X \beta+Z a+W p+e$ where: y = represents the observations of $\mathrm{BW}, \mathrm{PC}$ and $\mathrm{AFC}$ 
of each animal, $X$ is the incidence matrix for fixed effects, $\beta$ is the vector of fixed effects of contemporary group and covariate cow's age at calving (linear and quadratic effects), $Z$ is the incidence matrix for genetic additive random effect; $a$ is a vector of random genetic additive

effects of individual traits; $\mathrm{W}$ is the incidence matrix for maternal permanent environmental effect, $p$ is a vector of permanent environmental effects, and $e$ is a vector of random residuals.
Subsequently, the Spearman's correlation for the best-ranked bulls based on PC prediction were calculated using the breeding values of bulls with progeny for BW, PC and AFC.

The software REMLF90 (Misztal, 2002) was used for the estimation of variance components using the restricted maximum likelihood method and for prediction of solutions for random effects.

Number of records, means and standard deviation for $\mathrm{BW}, \mathrm{CP}$, structure, precocity, muscling, and AFC is showed in table 1.

Table 1. Number of records (N), means and standard deviation (SD) for BW, PC, structure, precocity, muscling, and AFC in females of the Nellore breed

\begin{tabular}{|c|c|c|c|}
\hline & $\mathrm{N}$ & Means & SD \\
\hline BW (kg) & 231416 & 235.51 & 34.63 \\
\hline S & 21057 & 4.18 & 0.93 \\
\hline $\mathrm{P}$ & 21057 & 4.02 & 0.94 \\
\hline M & 21057 & 3.76 & 0.96 \\
\hline AFC (months) & 15750 & 33.83 & 2.28 \\
\hline PC & 21057 & 6.86 & 1.38 \\
\hline
\end{tabular}

$\mathrm{BW}=$ body weight at 12 months of age, $\mathrm{S}=$ structure, $\mathrm{P}=$ precocity, $\mathrm{M}=$ muscling, $\mathrm{AFC}=$ age in first calving. $\mathrm{PC}=$ principal component.

\section{RESULTS AND DISCUSSION}

The number of records with means and standard deviations for BW, PC, body structure, precocity, muscling, and age at first calving (AFC) are shown in Tab. 1.

The first principal component (PC) was obtained through an orthogonal transformation of the first eigenvalue. It generated the first orthogonalized eigenvector, which converted the set of observations of $\mathrm{S}, \mathrm{P}$ and $\mathrm{M}$ into a linear combination equal to $\mathrm{PC}=$ $0.510377(\mathrm{~S})+0.592461(\mathrm{P})+0.623302(\mathrm{M}) . \quad$ It retained $71.14 \%$ of the total variation from the original variables ( $\mathrm{S}, \mathrm{P}$ and $\mathrm{M}$ ). The three eigenvalues and the proportion of the total variance accounted for by each component can be seen in Tab. 2 .

Thus, the principal component technique was efficient in reducing parameter space, in addition to transforming a set of discrete variables into a continuous variable.

Table 2. Estimates of eigenvalue and their ratio in explaining total variation

\begin{tabular}{lccc} 
Eigenvalue & Value & ratio & Cumulative ratio \\
\hline 1 & 1.9555 & 0.7114 & 0.7114 \\
2 & 0.5107 & 0.1858 & 0.8972 \\
3 & 0.2824 & 0.1018 & 1.0000 \\
\hline
\end{tabular}

Pearson's linear correlations between BW, S, P, $\mathrm{M}, \mathrm{AFC}$ and $\mathrm{PC}$ are shown in Tab. 3. Correlations between $\mathrm{BW}$ and other traits were moderate and positive in magnitude, except with AFC, which demonstrated favorable negative correlations with all the other traits.

Arq. Bras. Med. Vet. Zootec., v.72, n.3, p.955-960, 2020
By interpreting the influence of $\mathrm{S}, \mathrm{P}$ and $\mathrm{M}$ on the first principal component, it is observed that the three original traits had similar contributions to the referred component since the correlations between PC and the original variables were positive, significant, and of high magnitude ( $\mathrm{p}<$ 0.01). It indicates that PC can be safely used as a 
single index to represent the body conformation of animals.

Freitas et al. (2011) and Muniz et al. (2014) had success in using principal components analysis based on productive and reproductive performance of Nellore animals, but with different applications. Overall, heavier females at the age of 12 months old also expressed greater carcass conformation and sexual precocity.

Table 3. Estimates of Pearson correlations between traits of body weight at 12 months of age (BW) with first principal component $(\mathrm{CP})$, structure $(\mathrm{S})$, precocity $(\mathrm{P})$, muscling $(\mathrm{M})$ and, also, age of first calving (AFC) in females of the Nellore breed

\begin{tabular}{lccccc}
\hline & E & P & M & IPP & PC \\
\hline BW & 0.4241 & 0.3316 & 0.3841 & -0.2845 & 0.4475 \\
S & - & 0.4723 & 0.5080 & -0.1112 & 0.7573 \\
P & - & - & 0.6915 & -0.1369 & 0.8684 \\
M & - & - & - & -0.0885 & 0.8901 \\
AFC & - & - & - & - & -0.1314 \\
\hline
\end{tabular}

Estimates of variance components for genetic additive effects, maternal permanent environmental and temporary environmental effects, as well as heritability estimates for BW, PC and AFC traits are shown in Tab. 4.

Heritability estimates for $\mathrm{BW}$ and $\mathrm{PC}$ were of medium to high magnitude, indicating that their phenotypic value is a good indicator of direct genetic additive value. Consequently, the use of these traits as a selection criterion in breeding programs results in improvements in weight gain and carcass conformation in a shorter time period.
High heritability estimates for body weight at 12 months (0.56 and 0.68) were obtained by Nepomuceno et al. (2012) and Gonçalves et al. (2011), respectively. On the other hand, lower estimates were observed by Bertazzo et al. (2004), and Boligon and Albuquerque (2008), which were $0.42,0.24$; and 0.30 , respectively.

Koury Filho et al. (2009) and Faria et al. (2009) found heritability estimates for $\mathrm{S}, \mathrm{P}$ and $\mathrm{M}$ of $0.24 ; 0.63,0.48$ and $0.68,0.65$ and 0.62 , respectively, which were higher than those observed by Boligon et al. (2010), with values of $0.19,0.23$ and 0.20 , respectively. Those values were closer to the heritability estimate observed for PC.

Table 4. Estimates of variance components for genetic additive effects, maternal permanent environmental and temporary environmental effects, as well as heritability estimates for BW, PC and AFC traits, in females of the Nellore breed

\begin{tabular}{lccc} 
& \multicolumn{3}{c}{ Characteristics } \\
\cline { 2 - 4 } Variance components & $\mathrm{BW}$ & $\mathrm{PC}$ & $\mathrm{AFC}$ \\
\hline Genetic additive & 594.00 & 0.5114 & 0.9427 \\
Maternal permanent environment & 71.95 & 0.0485 & 0.0351 \\
Temporary environment & 491.80 & 1.1560 & 3.7440 \\
Heritability & 0.51 & 0.30 & 0.20 \\
\hline
\end{tabular}

Heritability estimates for AFC, although lower in comparison with $\mathrm{BW}$ and $\mathrm{PC}$, indicate that it is possible to obtain good responses based on its reduction through genetic selection. Along with good reproductive management practices, it would allow improvements in the reproductive efficiency of cows and economic efficiency in beef cattle systems.
The heritability estimates for AFC calculated in this study was close to the value of 0.14 reported by Nepomuceno et al. (2012), 0.16 as reported by Silveira et al. (2014) and Boligon and Albuquerque (2010) and 0.18 as reported by Boligon et al. (2008) and Dias et al. (2004).

Genetic additive correlations between $\mathrm{BW}$ and $\mathrm{PC}$; $\mathrm{BW}$ and $\mathrm{AFC}$, and also, $\mathrm{PC}$ and $\mathrm{AFC}$ were $0.48,-0.31$ and -0.55 , respectively. Estimates 
were favorable especially between PC and AFC, i.e., the selection of animals with better body conformation leads to the selection of earlymaturing females.

A common practice in herds is the adoption of minimum body weight to start the reproductive life of females. Thus, animals with early body development would also reach the age of first breeding earlier, leading to lower AFC values.

Along with the association of genetic correlations with heritability estimates, which are favorable to genetic progress, especially for BW, the selection of animals with higher genetic merit for BW and CP favor selection of early-finishing females due to the reduced age at first calving.

The correct identification and intense use of superior genotypes for BW, PC and AFC would result in superior offspring with greater performance. Consequently, it would allow higher genetic progress for body weight at 12 months, carcass conformation and sexual precocity over the years.
Faria et al. (2009) also reported that the use of visual appraisal scores as a selection criterion leads to genetic progress for reproductive traits as well. Moreover, Boligon and Albuquerque (2010) state that the inclusion of visual conformation (body structure), precocity and muscling scores in the selection indexes may increase the frequency of desirable genes for fertility and sexual precocity.

Koury Filho et al. (2009) reported estimates of genetic correlations between body structure and precocity of $0.49 ; 0.63$ between body structure and muscling; and 0.90 between precocity and muscling.

Predictions of breeding values for $\mathrm{BW}, \mathrm{PC}$ and AFC were obtained using a total of 6,714 bulls with daughters in production. The Spearman's correlation between the predictions of breeding values was calculated using data from bulls with at least 40 daughters, which corresponded to 890 bulls. The ranking of the 100,50 and $25 \%$ best bulls based on breeding values and PC were obtained using data from these 890 bulls and Spearman's correlation (Tab. 5).

Table 5. Number of sires, means and standard deviations (SD), minimum (Min.) and maximum (MAX.) observed values, Spearman correlations between breeding value estimates for BW and AFC for better sires selected in PC

\begin{tabular}{clccccccc}
\hline & & \multicolumn{3}{c}{ Parameters } & & \multicolumn{2}{c}{ Spearman correlation } \\
\cline { 3 - 5 } \cline { 7 - 8 } & & Mean & SD & Min. & Max. & & PC & AFC \\
\hline \multirow{2}{*}{$\mathrm{TN}=890$} & BW & 6.28 & 19.68 & -55.26 & 77.32 & & $0.56(\mathrm{p}<0.01)$ & $-0.39(\mathrm{p}<0.01)$ \\
& PC & 0.11 & 0.56 & -3.13 & 2.09 & & - & $-0.73(\mathrm{p}<0.01)$ \\
& AFC & -0.05 & 0.62 & -3.88 & 3.26 & & - & - \\
\hline $\mathrm{N} 1=445$ & BW & 15.78 & 17.49 & -53.49 & 77.32 & & $0.37(\mathrm{p}<0.01)$ & $-0.16(\mathrm{p}<0.01)$ \\
& PC & 0.52 & 0.41 & 0.06 & 2.09 & & - & $-0.46(\mathrm{p}<0.01)$ \\
& AFC & -0.39 & 0.59 & -3.88 & 0.82 & & - & - \\
\hline \multirow{2}{*}{$\mathrm{N} 2=222$} & BW & 20.79 & 19.08 & -53.49 & 77.32 & & $0.13(\mathrm{p}<0.05)$ & $-0.25(\mathrm{p}<0.01)$ \\
& PC & 0.84 & 0.36 & 0.41 & 2.09 & & - & $-0.38(\mathrm{p}<0.01)$ \\
& AFC & -0.61 & 0.70 & -3.88 & 0.82 & & - & - \\
\hline
\end{tabular}

$\mathrm{TN}=$ Total number of sires; $\mathrm{N} 1=50 \%$ better sires selected for PC; $\mathrm{N} 2=25 \%$ better sires selected for PC.

The mean breeding values for $\mathrm{BW}$ and $\mathrm{PC}$ increased whereas the mean predicted breeding values for AFC decreased after selecting the $50 \%$ and $25 \%$ best-ranked bulls for PC. Overall, Spearman's correlations were similar to genetic correlations between the evaluated traits, with negative estimates of the genetic merits of bulls for $\mathrm{BW}$ and $\mathrm{PC}$ with $\mathrm{AFC}$, and positive between $\mathrm{CP}$ and BW. Therefore, the selection of bulls with higher genetic values for BW favors the production of heavier progenies, as well as earlymaturing daughters.

Freitas et al. (2011) stated that the visual scores of body conformation, muscling and finishing precocity can be used to assist in the selection and prediction of sexual precocity of Nellore heifers at weaning and also at fifteen months of age, which corroborates with our study. 


\section{CONCLUSIONS}

Heritability estimates and genetic correlations for $\mathrm{BW}, \mathrm{PC}$ and AFC indicate probable success if selected together, with potential genetic gains. Genetic selection through an index represented by a linear combination of body structure, precocity and muscling visual appraisal scores in females allow favorable genetic changes aiming at reducing the age at first calving in Nellore females.

\section{ACKNOWLEDGMENTS}

The authors wish to thank the Conselho Nacional de Desenvolvimento Científico e Tecnológico (CNPq), Associação Brasileira de Criadores de Zebú (ABCZ), CAPES, and FAPEMAT for providing support to this research.

\section{REFERÊNCIAS}

BERTAZZO, R.P.; FREITAS, R.T.F.; GONÇALVES, T.M. et al. Parâmetros genéticos de longevidade e produtividade de fêmeas da raça Nelore. Rev. Bras. Zootec., v.33, p.11181127, 2004.

BOLIGON, A.A.; ALBUQUERQUE, L.G. Correlações genéticas entre escores visuais e características reprodutivas em bovinos nelore usando inferência bayesiana. Pesqui. Agropecu. Bras., v.45, p.1412-1418, 2010.

BOLIGON, A.A.; ALBUQUERQUE, L.G.; RORATO, P.R.N. Associações genéticas entre pesos e características reprodutivas em rebanhos da raça Nelore. Rev. Bras. Zootec., v.37, p.596$601,2008$.

DIAS, L.T.; FARO, L.E. ALBUQUERQUE, L.G. Estimativas de Herdabilidade para Idade ao Primeiro Parto de Novilhas da Raça Nelore. Rev. Bras. Zootec., v.33, p.97-102, 2004.

FARIA, C.U.; KOURY FILHO, W.; MAGNABOSCO, C.U. et al. Bayesian inference in genetic parameter estimation of visual scores in Nellore beef-cattle. Genet. Mol. Biol., v.32, p.753-760, 2009.

FREITAS, A.R.; SOUZA, J.F.; MOREIRA, A. Predição da precicidade sexual em bovinos da raça Nelore por meio de components principais. Rev. Ciênc. Agrár., v.54, p.153-158, 2011.

GONÇALVES, F.M.; PIRES, A.V.; PEREIRA, I.G. et al. Avaliação genética para peso corporal em um rebanho Nelore. Arq. Bras. Med. Vet. Zootec., v.63, p.158-164, 2011.

KOURY FILHO, W.; ALBUQUERQUE, L.G.; ALENCAR, M.M. et al. Estimativas de herdabilidade e correlações para escores visuais, peso e altura ao sobreano em rebanhos da raça Nelore. Rev. Bras. Zootec., v.38, p.2362-2367, 2009.

MELLO R.R.C.; FERREIRA, J.E.F.SOUSA, S.L.G. et al. Parâmetros genéticos de características reprodutivas em bovinos de corte e leite. Rev. Bras. Reprod. Anim., v.40, p.65-72, 2016.

MISZTAL, I. Remlf90 manual. 2016. Disponível em: <http://nce.ads.uga.edu/ ignacy/numpub/ blupf90/docs/remlf90.pdf $>$. Acessado em: 15 out. 2016.

MUNIZ, C.A.S.; QUEIROZ, S.A.; MASCIOLI, A.S. et al. Análise de componentes principais para características de crescimento em bovinos de corte. Semin. Ciênc. Agrár., v.35, p.15691576, 2014.

NEPOMUCENO L.L.; ANDRADE R.J.; LOPES F.B.; LIRA T.S. et al. Associações genéticas entre o perímetro escrotal e as características produtivas e reprodutivas em rebanho Nelore criado na região norte do Tocantins. Rev. Acad. Ciênc. Anim., v.10, p.253-261. 2012.

SILVEIRA M.V., SOUZA J.C., SILVA L.O.C., et al. Interação Genótipo $\mathrm{x}$ Ambiente sobre características produtivas e reprodutivas de fêmeas Nelore. Archivos de Zootecnia, v.63, p.223-226. 2014. 